\title{
Abbasid Golden Age and Sung Puzzle
}

\section{Introduction}

This chapter analyzes the long medieval era, from approximately 400 AD to $1300 \mathrm{AD}$. The defining military technological change of this era was the rise of the heavy cavalry which led to a small mass factor. The rise of heavy cavalry also led to the advance of nomads at the expense of settled societies, and the universal empires of the late classical era either retreated or dissolved. Fragmentation and creativity were the two prevalent themes among the major medieval cultures of Western Europe, the Byzantine Empire, South Asia, China, Japan and the Islamic world. Given the small mass factor, relativist concern was generally quite modest in the major cultures despite the rather even distribution of capability. The medieval major cultures therefore functioned significantly different from the familiar early modern European competitive state system with its strong emphasis on real politics and high relativist concern.

The medieval Islamic civilization deserves special attention here. The cultural energy and economic achievements of the Islamic civilization during its early era of unity and then the Abbasid Golden Age contradict the Hume-Kant hypothesis of Bernholz et al. (2004). According to the Hume-Kant hypothesis, one would look at the medieval Islamic world and expect to see a state system with independent states of roughly equal power. Similarly, the above average performance of China during the mighty Tang Dynasty also poses problems to the Hume-Kant hypothesis. The Tang Dynasty was definitely not a state system and was in fact about as powerful as the Han Dynasty before, or the Ming and Oing Dynasties that came later. By taking into account the effects of military technology on international political structure and, political military competition and economic performance, the arguments developed in earlier chapters successfully accounts for the achievements of the medieval Islamic world and the above average performance of Tang Dynasty China. The Chapter also treats the Song Puzzle in greater details. The high economic achievements of Song Dynasty China resonates very well with the early modern European Miracle and strongly supports the claims of Jones $(1981,1988,1990)$ that intensive growth was a recurring phenomenon in history.

The medieval era saw more significant political military competition at the pan Eurasian level. Besides the struggle between the Christendom and Islam in the Middle Eastern and the Mediterranean regions which in a way was a 
successor to the clash between the Romans and the Persians, there were many more political military interactions among the major civilizations. During the medieval era, the Abbasid Caliphate clashed with Tang China over central Asia, Islamic forces began their conquest of South Asia, Tang China and Japan fought in Korea, Tang China briefly exerted military influence in India, the southern Indian state of Chola sent naval expeditions to Southeast Asia, among others. These political military interactions at the pan Eurasian level culminated in the far reaching conquests of the Mongol Empire, the first truly pan Eurasian empire in history.

\section{Heavy Cavalry}

The Eurasian steppes saw the advent of selective horse breeding, which led to a powerful steed able to carry a fully armed and armored warrior at great speed, even when the horse itself was fully armored-and these newly-bred horses could then charge with great explosive power. The invention and use of stirrups and composite bows added further power to the cavalry: horse and rider were effectively welded into a lethal fighting unit. Consequently, the earlier battlefield reign of the massive light and heavy infantry legions came to an end, and until the gunpowder military revolution, the mounted shock combat of the heavy cavalry in combination with the mobile archers on horseback of the light cavalry ruled the battlefield. The Persians, in their long struggles against the Seleucid phalanxes and the Roman legions, pioneered this wave of military technological revolution, and soon the practice spread to the other parts of the Eurasian landmass. Naturally, peoples already used to riding on horses particularly embraced this military advance.

As the massive infantry legions which the universal empires of the classical agrarian world had relied upon lost their advantage in battle against the nomads on horseback, the steppe peoples gained greater military efficiency relative to the settled societies. Consequently, nomadic hordes advanced at the expense of the settled societies. The rise of the cavalry as the dominant military force changed not only the relative combined military economic efficiency between settled societies and nomads. This wave of military technological changes also reduced the returns to scale in warfare since cavalry relied less upon manpower and military mass in battle. Since the ancient agrarian empires had much more resources at their disposal than the steppe peoples, a decline in the mass factor further reduced the military advantage of the once-mighty agrarian classical universal empires, which therefore either retreated or dissolved. This wave of military technological changes affected all major Eurasian civilizations. 
Nomadic invasions led to either the collapse or the retreat of the classical universal empires around 400-600 AD. The aftermath was political fragmentation and decentralization. The decline of the Roman Empire, the Sassanid Empire of Persia, the Gupta Empire of India, and the Chinese Western Jin Dynasty happened almost simultaneously. ${ }^{107}$ The invasions came from many sources: Asiatic nomads from the steppe of central Asia, Arabian tribes from the desert of the Arabian Peninsula, and Germanic tribes from the northern and central European forests and plains. Massive empires collapsed into small kingdoms which in turn dissolved into tiny principalities.

The ascendancy of the cavalry over the infantry and the associated decrease in the economies of scale in conflict had economic and public financial consequences. Cavalry warfare was horse-intensive and had less need of manpower; pasture was the critical resource that supported the military on horseback. The fiscal capacity of the state became less important. Centralized states gave way to feudalism. Localized feudal relationships and exchanges replaced centralized unitary taxations and economic regulations and networks. This decentralization in the economic and fiscal arenas led to further fragmentation of the medieval geopolitical landscape. The consequence was a myriad of small kingdoms or short-lived and decentralized empires that came and went as charismatic or extraordinary leaders entered and exited the historical stage.

The heavy cavalry military revolution indirectly affected the relative combined military and economic efficiency of the major Eurasian cultures through another mechanism. Since the medieval form of warfare relied less on manpower but critically upon horsepower, the control of a dominant economic core area with abundant manpower became less important for maintaining military might. Consequently, even in regions where there was a single dominant core economic area with a concentration of an overwhelming share of resources and manpower, like China, the relative combined economic and military efficiency between the contestant controlling the dominant core economic area and contestants holding other lands became less asymmetric. The player controlling the dominant core now enjoyed less strategic advantage, since economic resources and a greater manpower supply could translate less into military might. As the relative combined economic and military function became more symmetric, there was a more even distribution of resources and capability within all the major cultures of the medieval era.

In order to meet the threat from the steppe nomads of Central Asia, Parthian and Sassanid Persia had replaced infantry legions with localized heavy and light cavalry as the core of its defense. Persia therefore decentralized its public

107 Refer to McNeill (1982), Dudley $(1990,1991,1992)$ and Keegan (1993). 
administrative apparatus. The Byzantine Empire partly emulated the Persian defense system: the decrease in the economies of scale in warfare led to decentralization and retrenchment of the Byzantium government in the $7^{\text {th }}$ century $A D$, which in turn led to the rise of feudalism. ${ }^{108}$ However, even the improved defense system could not protect Sassanid Persia against the onslaught from another group of nomads, the Islamic Arabs. ${ }^{109}$ In 632 AD, the first raiders from the Arabian tribes, recently united by Islam, reached Sassanid territory. Years of warfare had already exhausted both the Byzantines and the Sassanids. The Sassanids were further weakened by the increasing power of the provincial feudal lords and a rapid turnover of rulers. These factors facilitated the swift Islamic conquest of Persia.

The core area of the Roman Empire was the Mediterranean basin. The Roman Empire held together the many coastal regions of the Mediterranean Sea with its great fleets and massive infantry legions. With the rise of cavalry and the decline of infantry in warfare, it became nearly impossible to hold both the European northwestern coastal regions and the Asian-African southeastern coastal regions of the Mediterranean together under one empire. The Roman system was divided into two: the Western Roman Empire, and the Eastern Roman Empire, otherwise known as the Byzantine Empire. This division was soon followed by dissolution as the Western Roman Empire subsequently collapsed under waves of nomadic assaults, whilst the Byzantine Empire, despite the heroic attempts at resurgence by the Emperor Justinian, retreated under incessant nomadic invasions.

Under repetitive onslaughts from the nomadic tribes, the major classical empires of the settled civilizations abandoned the plains and retreated to mountainous and/or maritime regions of their former realms. These included the Eastern Jin Dynasty, the Southern Dynasties and the Southern Song Dynasty of China; the Hindu southern Indian states that confronted the Muslim powers which invaded and conquered the Indo-Gangetic Plain; the Byzantium Empire; and the Italian city-states that controlled much of the Mediterranean trade. It was the Deccan Highland in India and the Yangtze River in China that served as natural barriers to the power of the nomadic cavalry. As a response to the supremacy of cavalry warfare, the Byzantine and Persian armies increased the use of cavalry and came to look very much the same as the nomadic hordes. These remnant successor states of the once mighty late classical empires of the settled civilizations managed to long endure in regions where the military superiority of the cavalry was limited or annulled by geography.

108 Refer to Treadgold (2001, Ch. 4).

109 Refer to McNeill (1999, pp.194-209). 
The medieval era refers to the period from the collapse of the classical universal empires to the gunpowder military revolution that kick-started the modern era, that is, from around 400-1300 AD. Given the low level of economies of scale in conflict, fragmented pluralistic international orders-interrupted briefly by short-lived and decentralized empires-were the norm for the geopolitical landscape of the major Eurasian cultures. Stable, lasting and centralized imperial orders did not reappear on the Eurasian geopolitical scene till the arrival of the gunpowder military revolution.

During the long medieval era, there were many brief ambitious imperial attempts across Eurasia. In Europe, the short reign of limited unification under the Charlemagne Empire lasted 768-ca 850 AD. In the Middle East, the newborn Islamic Empire was united under the Umayyad Caliphate for a brief period of about a hundred years, from around 661-750 AD. In India, after the collapse of the Gupta Empire in the fifth and sixth centuries, political unification did not return until the arrival of the Delhi Sultanate, which briefly unified northern India in the thirteenth century. In China, the Tang Dynasty brought about a relatively short-lived unification from 618-755 AD. These brief imperial attempts pale in comparison to the long lasting uncontestable and stable imperial orders of the preceding late classical eras or the following gunpowder era.

The small mass factor of the medieval era had great political and geopolitical impact. For instance, Tibet, a state with a very small population and limited resources, sacked the capital of the Tang Dynasty three times. The Tibetan Empire ruled part of northeastern India as well but collapsed in around AD 850.110 Empires of this era had short reigns and were more contestable and unstable, and the international political orders were thereby less likely to suffocate creativity and developmental momentum. The unstable, contestable and shortlived empires of the medieval age were unlike the stable, uncontestable and enduring imperial orders of the ancient world. Nor were they similar to the stable, uncontestable and very secure continental-sized empires of the gunpowder era. These medieval empires, given their insecurity and decentralized structure, were never as entrenched and complacent as the classical empires or the gunpowder empires. Furthermore, their reigns were not long enough to choke off creativity and developmental momentum, which was in fact generated by the interstate rivalry of the pluralistic and fluid international orders which ruled the Eurasian world for most of the medieval era. A time of international instability and fragmentation, the medieval era was also, somewhat surprisingly, a time of innovations, development and progress.

110 Refer to Grousset (1970, pp. 80-114) and McNeill (1999, pp. 224-227). 
The creativity and energy of the medieval civilizations were not as splendid or spectacular as those of the classical Greek, Ganges Indian and Chinese civilizations or the early modern European civilization. For given the low economies of scale in warfare, political military competitions within the different medieval major cultures were also less intense compared to those of the classical Greece, Ganges India and China or early modern Europe. Nonetheless, all major medieval cultures developed and there were no spectacular differences. ${ }^{111}$ Low economies of scale in warfare caused all major cultures to operate under pluralistic international orders, such as state systems, during most of the medieval era. Consequently, developmental performance was much the same across Eurasia. McNeill (1963) termed it "the rough equilibrium" among the major cultures.

One manifestation of the medieval energy and creativity was the expansion of the various civilizations. Christendom expanded to Northern and Eastern Europe. ${ }^{112}$ Islam expanded into sub-Saharan Africa (after 1000 AD), eastern Africa, India, Central Asia, and Europe; after 1200 AD, Islam spread to Southeast Asia as well. ${ }^{113}$ China exerted its influence into Yunnan, Manchuria, southern Siberia, Central Asia, Taiwan, and the Ryukyu Islands, and spread its cultural influence into Japan. The southern India Hindu states expanded into Southeast Asia. ${ }^{114}$ Each major culture will be surveyed in turn.

\section{Middle East}

The conquests of the nomads brought a new major player into the Eurasian world of civilizations: the Islamic civilization. Bursting out from the Arabian Desert with great religious zeal and unity, the Arabian tribesmen under the banner of Islam soon conquered Sassanid Persia and wrested from Byzantium the wealthy provinces of Egypt, Syria and the Levant. From 661-750 AD, the Umayyad Caliphate conquered and unified the Iberian Peninsula, northern Afri$\mathrm{ca}$, the Middle East and Central Asia under one faith. The warmer and more arid southern and eastern coastal regions of the Mediterranean world were now separated from the colder and more forested Western world, a separation that persists to this day. Yet the unified Islamic empire did not last long.

111 Refer to Abu-Lughod (1989) and Chaudhuri (1990).

112 Refer to McNeill (1999, Ch. 14, 16).

113 McNeill (1999) observes "In East Africa, the effort required to resist Islamic assault actually generated something of a 'golden age' in Abyssinia's cultural history......" (277) 114 Refer to Haywood (1997, pp. 32-33). 
The Arabs were originally nomads and therefore initially enjoyed high relative combined military and economic efficiency versus their settled rivals given the medieval form of warfare in which the cavalry played a dominant role. This high asymmetry in relative combined military and economic efficiency facilitated the creation of an empire. Furthermore, the initial strong appeal of a new universal religion and the strong bond it created among the Arabian tribesmen generated a short-lived condition of even higher asymmetry in relative combined military and economic efficiency. These favorable conditions generated a very high concentration of resources and capability and made possible the century-long unification of the Islamic world under the Umayyad Caliphate. However, political unity was rare during the medieval era, due to the small economies of scale in warfare of the medieval military technology. As the initial religious zeal faded and the Arabian tribesmen settled and lost some of their equestrian skill, relative combined military and economic efficiency became more symmetric. Consequently, the distribution of resources and capability also became more even and the unified Islamic empire began to breakdown.

With medieval military technology it was difficult to maintain a unified imperial rule throughout the Islamic world (or indeed anywhere across Eurasia) for long. After the Umayyad Caliphate, political fragmentation was the norm in the Islamic world. During the long rule of the succeeding Abbasid Caliphate which lasted from $750 A D$ to 1258 AD, political fragmentation was in fact the norm in the Islamic world. The Islamic world under the Abbasid Caliphate could be aptly described as a state system or a pluralistic international order, for among the many contestants in the Middle Eastern Islamic world, there was a fairly even distribution of capability. It was during this period of political fragmentation that saw the realization of the great Islamic achievements. ${ }^{115}$

The Abbasid Caliphate failed to unite the whole Islamic world: Egypt was autonomous, as were the Aghlabids of Tunisia and Algeria, and the Persian dynasties of the Tahirids and Saffarids. Furthermore, a descendent of the Umyaad Caliphate escaped to the far flung Spain to reestablish the Umyaad rule there. Above all, the Abbasid Caliphate still had to contend with the Byzantine Empire on the international scene. The reliance on Turkish slave soldiers for defense and regime maintenance also meant that the Abbasid Caliphate was far from monopolizing the capability of coercion and conquest. The authority of the Abbasid Caliphate was more religious and de jure than political and de facto. Consequently, there was a pluralistic international political order in the early

115 Refer to Ruthven (2004) for the geopolitical landscape of the Islamic world in history. Refer to Huff (2004) in Bernholz and Vaubel ed. (2004, pp. 204-210) for the Islamic golden age of scientific creativity during this era. 
and mid-medieval era in the eastern Mediterranean and Middle East-Persia region. ${ }^{116}$

The following centuries saw a number of states came and went in the Middle East. In the mid- and late medieval era came the Turkish empires of the Ghaznavids and Seljuks. In 909 AD the Fatimid Dynasty was established in Tunisia and Egypt. Not much later the Ayyubid Dynasty was installed in Egypt and Syria, followed by the Egyptian Mamluk Dynasty, the Buyid Dynasty (established 945 AD) in Iraq, the Oarmatians in Bahrain, the Samanids in Eastern Persia, the Hamdanids in Northern Iraq, and many states set up by the Seljuk Turks. The fluid geopolitical landscape was frequently and swiftly reshaped again and again, mainly due to the small economies of scale in medieval warfare which made political regimes highly contestable. Consequently, complacency had very little chance of sinking in.

The enervation of the Arabian tribesmen created a vacuum in the military sector of the Islamic empire which was swiftly filled in by soldiers of Turkish origin. Although individual Turkish generals had already gained considerable, and at times decisive, power in Mesopotamia and Egypt during the tenth and eleventh centuries, the coming of the Seljuks signaled the first large-scale penetration of Turkish elements into the Middle East. Descended from a tribal chief named Seljuk, whose homeland was beyond the Oxus River near the Aral Sea, the Seljuks developed a highly effective fighting force. Furthermore, through their close contacts with Persian court life in Khorasan and Transoxania, the Seljuks also attracted a body of able administrators. Extending from Central Asia to the Byzantine marches in Asia Minor, the Seljuk state under its first three sultans-Tughril Beg, Alp-Arslan, and Malikshah-established a highly cohesive, well-administered Sunni state under the nominal authority of the Abbasid caliphs at Baghdad. This and later Turkish states coexisted with the many other small Islamic kingdoms in the Middle East and Northern Africa during the long medieval era.

The Islamic pluralistic international order was maintained until the Mongol invasion of the Middle East at the dawn of the gunpowder military revolution. Therefore, there was an increase in the symmetry of relative capability in the transition from the moderate or highly stable imperial order (as seen under the earlier Parthian and Sassanid Empires) to the medieval Islamic pluralistic international order. The medieval era was a period of frequent political chances and contests and wars for the Islamic world, but it was also a period of dynamism, energy and achievements which culminated in the Abbasid Golden Age. ${ }^{117}$

116 Refer to Goldschmidt (2002, Ch. 6).

117 Refer to Goldschmidt (2002, Ch. 7). 
Politically, culturally, and economically, there were many achievements under the Abbasid Caliphate. This period experienced the Arab agricultural revolution, with the widespread diffusion of new crops and the promotion of new or the rehabilitation of old irrigation systems. ${ }^{118}$ Trade was thriving and Arabian traders were at the center of the global trading network. Arabian and Islamic trading communities could be found throughout Eurasia: in Europe, Central Asia, India, Southeast Asia and China. Islamic merchants pioneered many innovations in business organization and finance: capital was pooled through partnerships, and letters of credit and promissory notes facilitated long distance trade. ${ }^{119}$ There was intensive economic growth and a high level of urbanization and trade. ${ }^{120}$ The city-states of Islamic Spain for instance achieved splendid cultural achievements and a high level of economic prosperity during this period. ${ }^{121}$

Politically, this period saw many outstanding statesmen and administrators. For example, the Persian Nizam-al-Mulk was one of the greatest statesmen of medieval Islam. For twenty years, especially during the rule of Sultan Malikshah, he was the true custodian of the Seljuk state. Besides being a great administrator, he was an accomplished writer and well known for his style: his book on statecraft, Siyasat-Namah, stresses the responsibilities of the ruler and is a valuable source for the political thought of the time. For instance, he argues that if a man is killed because a bridge is in disrepair, it is the fault of the ruler: he argues that the ruler should make it his business to appraise himself of the smallest negligence of his underlings.

Nizam-al-Mulk was a devout and orthodox Muslim who established a system of madrasahs, or theological seminaries (also called nizamiyah, after the first element of his name). These madrasahs provided students with free education in the religious sciences of Islam, as well as in the most advanced scientific and philosophical thought of the time. Many great scholars taught in these seminaries. For example, the famous theologian al-Ghazali (whose greatest work, The Revival of the Sciences of Religion was a triumph of Sunni theology) taught for a time at the nizamiyah schools in Baghdad and in Nishapur. Furthermore, Nizam-al-Mulk was the patron of the poet and astronomer Umar al-Khayyam (Omar Khayyam) whose verses, as translated by Edward FitzGerald in the nineteenth century, have become almost as familiar to English readers as Shakespearean sonnets.

118 Refer to Watson (1974).

119 Refer to Cahen (1970, pp. 511-38) in Holt, Lambton and Lewis ed. (1970) and AbuLughod (1989).

120 Refer to Jones (1988).

121 Refer to Wesson (1978, pp. 93-95), Abu-Lughod (1989), Armstrong (2000, pp. 45-

81), Sonn (2004, Ch.2) and Bernholz (2004, pp. 184 - 193) in Bernholz and Vaubel (2004). 
On the legal front, the Abbasid Era was the period in which Islamic law developed on a broad basis and the overall framework was established for all aspects of legal institutions. Laws relating to commerce and property were especially highly developed. The Islamic world during this period had already developed advanced legal concepts and practices on bankruptcy, partnership, trust, conveyance, and inheritance. That greatly facilitated the functioning of the highly commercialized economy. However, the overall development of Islamic law ended around the $13^{\text {th }}$ century, a time that roughly coincided with the ending of the medieval Abbasid Golden Age of the Islamic world. Stagnation in legal thinking then dominated the next few centuries in the Middle Eastern world. ${ }^{122}$

Scientific achievements of the Abbasid Caliphate were noteworthy. In Baghdad, there was caliph al-Ma'mun's Bayt al-Hikmah, a great learning center. Astronomy and mathematics saw great advances: the period saw the manufacturing of astrolabes and the building of planetariums, and Islamic scientists knew that the earth orbited the sun earlier than Copernicus or Galileo did. The greatest Islamic mathematician, Muhammad ibn Musa (780-850 AD), wrote on the Hindu numeral system and popularized it-and as a result the system we use today is known, somewhat unfairly, as the Arabic numeral system. He compiled a textbook on algebra (itself a word derived from Arabic), and this book was used in both East and West for centuries; he also formulated the oldest trigonometric tables known, and collaborated with other scholars in preparing an encyclopedia of geography.

Advances in medicine and chemistry were equally splendid. In medicine there was the well-known Vesalius. ${ }^{123} \mathrm{Ibn}$-Sina (Avicenna) wrote a widely used Canon for medicine. ${ }^{124}$ Sophisticated laboratory techniques for handling drugs, salts and precious metals were developed. ${ }^{125}$ Of all fields of medicine, Islamic achievements were greatest in ophthalmology. Physicians performed sophisticated surgeries including the earliest removal of cataracts. In the field of history, Ibn Khaldun, the North African polymath, produced his great work Kitab al-Ibar on universal history of which the famous first volume, Muqaddimah, is known in the West as Prolegomenon.

Collectively, the economic, political, cultural, legal, and scientific achievements of the medieval Islamic civilization were so great that they profoundly affected the course of human civilization and overshadowed those in the later periods of Islamic history. This pluralistic era of the Islamic world, known for its great cultural and economic achievements, is therefore known as the Abbasid

122 Refer to Wigmore (1928, pp. 541-542, 555-573).

123 Refer to Goldschmidt (2002, Ch. 8).

124 Refer to McNeill (1999, p. 246).

125 Refer to Stavrianos (1982, pp. 23-235) and McNeill (1999, pp. 219-220). 
Golden Age. Through conquests, trade and cultural exchanges, Islamic influences during this period expanded from Middle East into South Asia, Central Asia, Southeast Asia, Europe, Sub-Saharan Africa and East Asia.

\section{South Asia}

India was affected by the heavy cavalry revolution quite early. The Gupta Empire was weakened by nomadic invasions soon after establishing its hegemony, and the South Asian subcontinent sank into prolonged political fragmentation following the retreat and collapse of the Gupta Empire. Hordes of nomads from Central Asia invaded north India in the early $6^{\text {th }}$ century AD. ${ }^{126}$ The succeeding Harsha Empire ruled over only parts of northern India, and as a whole, the subcontinent operated under a pluralistic international political system until the brief unification under the Delhi Sultanate (ca 1200 AD).

Compare to medieval India, late classical India including the Gupta era also had a largely even distribution of capability. The decrease in economies of scale in warfare following the rise of the heavy cavalry therefore reduced political military competition in India. Given the multiple core areas of India, interregional warfare was mostly aimed at the control of intermediate regions, or was simply for the acquisition of goods or prestige. A rough balance of power was maintained: rulers were unable to extend their control beyond their respective regions as their military equipment, administrative machinery and strategic concepts were roughly equivalent. However, given the rather equitable distribution of military capability, there was still considerable concern for overall state power. Furthermore, the establishment of Islamic states in northern India increased pressure on Hindu states in southern India. Under such competition, there was still considerable developmental drive and effort taking place, albeit not at the level of the earlier Gupta golden age era.

On the whole, developmental achievements did not lag far behind those of the Arabian or Chinese systems. The south Indian Chola Empire and Vijayanagar Empire, for instance, were renowned for their high level of prosperity brought about, and maintained by, extensive external maritime trade and a powerful army and navy. The Vijayanagar Empire, 1336-1565 AD, had a powerful navy and dispatched naval expeditions to Southeast Asia. Its predecessor, the maritime south Indian Chola Empire, was also a thriving trading empire that had sent naval expeditions to Southeast Asia. There was a strong Indian influence

126 Refer to Kulke and Rothermund (1998, pp. 89-91). 
in Southeast Asia during this era. ${ }^{127}$ The southern Indian power of the Cholas conquered Sri Lanka and sent both troops and trading fleets to the Ganges region, Indonesia, Malaya and the Maldives, enabling the great merchants of south India to play a central role in international trade. ${ }^{128}$ Culturally, this period produced Bana, one of the greatest Sanskrit writers. ${ }^{129}$

\section{The Byzantine Empire}

The medieval ascendancy of heavy cavalry reduced the relative combined military and economic efficiency of the Byzantine Empire versus its many enemies, especially the nomadic tribes and Middle Eastern powers with strong cavalry. The associated decrease in economies of scale in warfare further weakened the Byzantine strategic position. The wealth and resources of the Byzantine Empire mattered less militarily. The Justinian effort to maintain the glory and integrity of the Roman Empire under a vastly different and much more disadvantaged military technology ultimately failed. Western Roman territories recaptured under Justinian rule failed to be held for long, and most were in fact lost again before the end of Justinian's reign. Consequently, the military technological changes resulted in a more even distribution of resources and capability in the Byzantine geopolitical sphere during the medieval era.

The Byzantine Empire lost its command of the preponderant share of resources and capability within its geopolitical sphere. Greatly weakened and shrunken, the Byzantine Empire had a higher relativist concern than the mighty Roman Empire had had. In the late classical era, the Roman Empire enjoyed an extremely high asymmetrical distribution of capability and a larger mass factor: it had become a very secure, stable and uncontestable empire with a very low relativist concern and an extremely risk-averse power-induced risk attitude. The change in fortune from the Roman Empire of the late classical era to the medieval Byzantine Empire therefore caused an increase in relativist concern and a more moderate risk attitude. There were therefore greater efforts in development and fewer distortions in economic decisions. So while the deteriorated political military condition may initially seem negative for Byzantium, the result was in fact the so-called Byzantine renaissance-a rebirth that left behind Roman imperial conservatism, indolence and insolence, Roman vices that Emperor Justinian deplored and campaigned against.

127 Refer to Haywood (1997, pp. 30-33).

128 Refer to Kulke and Rothermund (1998, pp. 109, 115-151).

129 Refer to Kulke and Rothermund (1998, pp. 103-107). 
The Byzantine economy was among the most prosperous and advanced in Europe and the Mediterranean world. The most important economic pillar of the empire was trade. Constantinople was the center of a trading network that spanned practically the whole of Eurasia and North Africa. The legislative work completed during the reign of Emperor Justinian, Corpus Juris Civilis, an extensive revision of the ancient Roman legal code remarkable for its sweeping character, is a collection of laws that came to be referred to as "Justinian's Code" and was instrumental in inspiring the revival of Roman laws in Western Europe during the high middle ages.

The Byzantine renaissance was not an exception during the medieval era. Under incessant assaults from the nomadic tribes, often viewed as barbarians by the settled societies, the deteriorating military environment prompted increased efforts on the part of the retreating classical empires, or their remnant successor states, to compensate for their declining strategic superiority. Around 600-700 AD, both the Byzantine Empire and Sassanid Persia increased their developmental efforts and generated some kind of renaissance and resurgence. Good examples include the formation of Alexandria's New Aristotelian Academy and Sassanid Persia's Jundishapur as famous learning centers. ${ }^{130}$

The once-great states, now under threat from "barbarian" cavalry, strove to acquire security through greater economic might and indeed, some managed to hang on even until the arrival of the gunpowder era. The Byzantines experienced a strong renaissance during the mid-medieval era partly due to political competition with the Islamic world. ${ }^{131}$ Led by Greek Christians in the Byzantine Empire, this vigorous Hellenic renaissance was ended by the Ottoman Turks in 1453 AD, but echoes of the Hellenic renaissance continued to be felt in Italy, whose own renaissance was significantly stimulated by the earlier Byzantine resurgence. ${ }^{132}$

\section{Europe}

With the rise of Islam, Christendom lost the North African coastal regions of the Mediterranean basin, together with the Levant and the bulk of the Iberian Peninsula. Of the vast realm of the Roman Empire, medieval Christendom retained basically only France and Italy, besides those lands still held by the much reduced and humbled Byzantine Empire. Christianity, however, compensated by adding northwestern Europe to its domain.

130 Refer to Goldschmidt (2002, Ch.8, p. 136).

131 Refer to Huff (1998, pp. 204-210) in Benholz and Vaubel (2004).

132 Refer to McNeill (1999, pp. 250-251). 
With North Africa and the Middle East lost and northwestern Europe added, Christendom, unlike the Roman Empire, had no single dominant core area. Christian Europe was geographically more fragmented than China, India, and the Middle East, or than the former Roman Empire. The loss of the North African and Middle Eastern lands to the Islamic world caused the core area of the ancient Western world, the Mediterranean basin, to decline in importance relative to the marginal lands of Northern and Western Europe: the Mediterranean, once the center of one world, instead became the border between two. The center of gravity in Europe shifted north, and the population of Northern Europe overtook that of the Christian Mediterranean world around 800 AD.

The geopolitical configuration of the Western world changed from that of a single dominant core area, centered on the Mediterranean basin, into one with multiple core areas in Northern and Western Europe. The more fragmented geography of northwestern Europe gave it a smaller mass factor than the other major civilizations with the same military technology. Moreover, empire-building was disadvantaged by the prevalent military technology, and consequently the Carolingian Empire built by Charlemagne the Great could only be sustained under that man's exceptional leadership: the empire broke down quickly after his death.

Medieval Europe had two aspirants to universal imperial power: the Holy Roman Empire and the Papacy. Both however fell far short of being a truly imperial power by the standard of the classical Roman Empire. While the reign of the Charlemagne over his empire was too short, the rule of the Holy Roman Empire was too decentralized. Moreover, by the late medieval era, even these modest pretenders to imperial power were facing encroachment and undermining from the rising power of trading cities, regional princes and national states. Consequently, Europe had a highly pluralistic international order throughout most of the long medieval era.

Given the small medieval mass factor, the highly even distribution of capability in Europe generated a moderate level of relativist concern and developmental drive. Furthermore, given that the distribution of capability was quite even, the power-induced risk attitude was largely risk-neutral. The yoke of imperial conservatism due to a high concentration of power of the Roman era was lifted for Europe. The continued development of the Western legal tradition during the medieval era is important evidence of European vigor and drive during this era. First, there was the effort in the Byzantine Empire of Justinian's Code. ${ }^{133}$ After that came the efforts made in Southern and Western Europe to revive Roman law, after the chaos of the Dark Ages had ended. There

133 Refer to Tellegen-Couperus (1993) on the history of Roman law. 
was also the development of canon law under the leadership of the Papacy and the autonomous development of merchant law and maritime law by the merchant community and the trading city-states. In fact, according to Berman (1983, 2003), the legal foundation of modern Europe and the modern world as a whole was laid down during the medieval era. ${ }^{134}$

The most advanced region of medieval Europe was Italy, partly because the Italian peninsula inherited much of the ancient Roman heritage. This heritage, in combination with the proximity to the Middle East and the Byzantine Empire, made Italy the forerunner in economic development in the Western world. Furthermore, northern Italy has a compact geography and was shielded from the imperial power of the Holy Roman Empire. The geographical barrier imposed by the Alps and the prestige and power of the Papacy neutralized the imperial power of the Holy Roman Empire in Italy and allowed the existence of a highly independent mini state system.

The rivalry between the Holy Roman Empire and the Papacy gave the citystates of Italy much de facto sovereignty; the Holy Roman Empire and the Papacy, as well as the Alps, in turn shielded Italy from the other great powers. This was the geopolitical basis of the mini city-state system of Italy. ${ }^{135}$ The compactness of the northern Italian plain meant that even with medieval military technology, warfare and military contests between constituent political units were quite decisive and intense. That is to say, the medieval Italian city-state system with its compact geography had a larger mass factor than the greater European system which had a multiple core areas fragmented landscape.

The even distribution of capability in Italy and the greater mass factor produced a very high level of relativist concern. The result was the Italian premium cultural and economic position in medieval Europe and the splendid Italian Renaissance. In contrast, the more fragmented and compartmentalized geography of northwestern Europe dented the sharp edge of international political-military competition and diluted the drive for greater power and economic development.

Italian city-states engaged in intense rivalry against each other, as well as against external powers. The intense political-military competition generated a high development drive. Furthermore, given that the distribution of capability was highly even within Italy, there was no extreme power-induced risk attitude to distort decisions including economic one.

134 Refer to Blum and Dudley (2003) on how Latin as a lingua franca aided economic growth in medieval Europe.

135 There were mini city-state systems elsewhere, such as in the southern part of France. These other mini city-state systems were later subsumed under the nation states and did not last as long as in the Italian city-state system. Refer to Wesson (1978). 
The commercial and naval rivalry between Venice and Genoa is famous: Venetian and Genoese navies dominated the Mediterranean Sea. ${ }^{136}$ For instance, in the fifteenth century, Venice had some three thousand ships, ensuring its position as one of the great powers of Europe, and that Venetian navy was in fact the chief European bulwark against Turkish powers in the Mediterranean. The power of Venice is again indicated by its successful defense of sovereignty against a league of the Papacy, the Holy Roman Emperor, France, Spain, and some minor powers in 1508 AD.

These Italian city-states achieved an amazing level of prosperity besides being very productive culturally. Despite constant wars between the city-states, Italy remained the richest region in Europe: for example, the revenues of Florence in the fourteenth century were surpassed only by those of the king of France. It has been claimed that the cities of northern and central Italy alone possessed more wealth than the rest of the European continent combined. ${ }^{137}$

Collectively, the Italian city-states bestowed to the later world institutional innovations such as the civilian control of the military, marine premium insurance (which began in Genoa ca 1350 AD), and the double entry accounting system (which they learned from the Arabian merchants). ${ }^{138}$ Of course, it is their cultural achievements, collectively termed the Renaissance, or "revival of learning", that are best known to us. Effectively, the European competitive state system, as well as the European Miracle, started in northern Italy. In a way, the relationship between Renaissance Italy and the European state system was analogous to the relationship between the city-state system of classical Greece and the succeeding Hellenistic era territorial state system. A mini state system ushered in a larger state system which was its intellectual inheritor. Splendid indeed was the vigor generated by the competitive rivalry among the citystates of Italy.

\section{China}

In China, like elsewhere, the advent of the medieval form of warfare reduced economies of scale in conflict. Since China itself during Oin, Han and Jin Dynasties was the dominant power in the Chinese international political system and commanded the lion's share of resources and capability within the system, the diminished mass factor brought forth a more even distribution of resources and

136 Refer to Wesson (1978, p. 159).

137 Refer to Wesson (1978, p. 158).

138 Refer to McNeill (1982) and Haywood (1997, p. 170). 
military capability. The medieval military revolution also caused the settled agrarian Chinese society to enjoy lesser relative combined military and economic efficiency versus the nomads on horseback. The adverse shift in relative efficiency reinforced the effect of a smaller mass factor to dissolve the gigantic Chinese empire of the late classical era, and the result was a pluralistic international political system in the medieval Chinese world.

In China, the reign of the Han Dynasty ended around 220 AD. It was succeeded by the Period of the Three Kingdoms (220-280 AD), an era of civil wars. The indigenous Chinese Western Jin Dynasty united China in 280 AD, but soon fell victim to rampant intra-elite power struggles and exhaustive civil wars, and was unable to defend northern China against nomads within and beyond the borders. Under incessant nomadic assaults, the Jin Dynasty retreated to southern China in 317 AD. Until ca 581 AD, a series of five indigenous Chinese dynasties reigned in southern China: the Eastern Jin Dynasty (317-420 AD), the Song Dynasty (420-479 AD), the Chi Dynasty (479-502 AD), the Liang Dynasty (502-557 AD), and the Chen Dynasty (557-589 AD).

After the Jin Dynasty had retreated to the south, northern China plunged into complete chaos for over a century. Nomadic tribes and Chinese regional powers engaged each other in messy warfare. This period (308-439 AD) is known as the "Era of Sixteen Kingdoms by Five Tribes of Barbarians" in Chinese history. This is the Chinese counterpart of the Dark Age of Europe after the collapse of the Western Roman Empire. Stable governance only returned ca 439 AD to northern China under the authority of the Northern Wei Dynasty (386-534 AD), a regime formed by nomads. After the Northern Wei Dynasty, northern China was divided between, on one side, the Eastern Wei Dynasty (534-550 AD) and its successor, the Northern Chi Dynasty (550-577 AD); and on the other side, the Western Wei Dynasty (535-557 AD) and its successor, the Northern Zhou Dynasty (557-581 AD). The Sui Dynasty finally unified northern China as well as southern China, in the latter part of sixth century. However, the reign of Sui Dynasty was very short, lasting less than three decades. Sui Dynasty was soon replaced by the Tang Dynasty after a brief period of civil wars.

During this period of prolonged political fragmentation, there were many famous battles where small forces defeated opponents who were numerically superior. These victories attest to the smaller medieval mass factor which increased the chances of success of the smaller forces against bigger fish in military contexts. The more famous of these battles include the Battle of Guandu (200 AD), where Cao Cao defeated Yuan Shao; the Battle of Chi Pi ( 208 AD; the Battle of $\mathrm{Chi} \mathrm{Pi}$ is also known as the Battle of Red Cliffs), where the alliance of Sun Quan and Liu Bei defeated Cao Cao; and the Battle of Fei Shui (383 AD), where the Chinese Eastern Jin Dynasty of southern China defeated the nomadic Qin Dynasty of northern China. The many battles won by Li Shi Ming (Emperor Tai Zong) of the Tang Dynasty were also victories for numerically inferior forces. 
The change from the late classical Chinese empire to the medieval pluralistic Chinese international political system intensified political military competition and generated higher relativist concern despite the small medieval mass factor. It also freed China from the extremely risk-averse power-induced risk attitude of the late classical era and delivered China from the yoke of imperial conservatism and severe economic distortions due to an extreme risk-averseness. Consequently, creativity and developmental drive returned to China.

In this era of fragmentation, decentralization and instability, the grip of Confucianism on the Chinese mind loosened. A good example was the statesman Cao Cao, the de facto founder of the Kingdom of Wei of the Era of Three Kingdoms. Many of his policies were contradictory to Confucian teachings, and Chinese historians have classified him as a Legalist. Further evidence of the decline of Confucianism was the popularity of Naturalist Taoism among Chinese intellectuals. There was more individual creativity in the cultural arena as well: poetry enjoyed resurgence and literature showed a liberal tendency. Additionally, there were innovations in political institutions: these innovations produced the institutions which were inherited by the Tang Dynasty and copied throughout East Asia, including in Japan. ${ }^{139}$

Under the threat of the nomadic regimes in northern China, the indigenous Chinese dynasties in control of southern China made many efforts to advance the economy. In the ancient era, China had one core region: the northern China Plain and the banks of the middle and lower stretches of the Yellow River. Due to the development of southern China from the third to sixth centuries, by the Sui and Tang Dynasties, the economic strength of the south became considerable and had already caught up with that of northern China: another core area had thus arisen. The Sui Dynasty constructed the Grand Canal and tapped the economic resources of southern China for maintaining the imperial regime in the north. Henceforth, the two regions were merged into a single dominant economic core area.

Nomadic invasions and dynastic turnovers plagued medieval China. Even the famous Tang Dynasty achieved only a short unification of about a century and a half, unlike the Han Dynasties whose unified empires had lasted for more than four hundred years. The Tang Dynasty and the very brief Sui Dynasty were much weaker imperial regimes than the Oin and Han Dynasties, given the smaller medieval mass factor. That is to say, since medieval military conflicts were more indecisive and favored the stronger contestant less, the imperial power became less entrenched and secure, and faced more political-military

139 Refer to Wesson (1967, pp. 377-378). 
challenges from within and beyond the border. The Tang Dynasty therefore had a higher relativist concern compared to the Han Dynasty.

The early Tang Dynasty enjoyed about a century of stability and prosperity due to a succession of three capable emperors: Emperor Tai Zong (who reigned from 627-649 AD), the de facto founder of the dynasty; Empress Wu (who reigned from 684-705 $A D$ ), the only female emperor in Chinese history; and Emperor Xuan Zong (who reigned from 712-756 AD). (In a way, their centralizing reigns, during a time more conducive towards decentralization, are analogous to Charlemagne's control of the Carolingian Empire: in both regions, only exceptionally skillful leaders could hold large empires together.) Consequently, notwithstanding some counterproductive policies of confiscation and government control and an underutilization of technology, there were considerable economic and cultural achievements during this era. ${ }^{140}$ During this time, Tang China and the Islamic Arabian world were the most advanced regions of the world.

The Tang Dynasty produced a significant proportion of China's greatest poets and essayists; internal commerce and external trade thrived; the merchant class again enjoyed the freedom and high status they had been deprived of during the Oin, Han and Jin dynasties. The culture and political institutions of the Tang Dynasty spread to surrounding countries, including Japan. One of the two most important achievements in Chinese legal history, the Kai Huang Lu (the Kaihuang Code), compiled in the Sui Dynasty, laid down the basic legal institutional framework for China from the Tang Dynasty to the Oing Dynasty: a long-lived legal tradition indeed. ${ }^{141}$

Given the medieval military technology, centralized governance was hard to maintain, even in China. The reign of the central government of the Tang Dynasty lasted approximately a hundred years. The rebellions of An Lu Shan and Shi Si Ming from 755-761 AD ended the de facto control of the central government. China after the rebellion was politically fragmented in fact if not in name. Consequently, the Tang Dynasty failed to have an imperial rule that was long and secure enough to completely stop the momentum of growth and creativity that had accumulated during the earlier era of political fragmentation and competition.

More often than not, there was a de facto state system or pluralistic international order operating in medieval China, even if historical records often claim a dynasty was in charge. The contestants were of diverse origins: Chinese, Turkic, Tungusic, or Mongolian, or Tibetan or others. The more even distribution of capability intensified political-military competition, raised relativist concern,

140 Refer to Mo (1995; 2004, pp. 57-74) and Bernholz and Vaubel (2004, p. 5).

141 Refer to Head and Wang (2005). 
reduced the power-induced risk averseness of the imperial regime and produced a high developmental drive that propelled China to first recover from the chaotic aftermath of collapse of Western Jin Dynasty rule in northern China, and then to reach the high achievements of the Tang Dynasty, Five Dynasties and Song Dynasty eras.

From the end of the rebellions of An Lu Shan and Shi Si Ming until the formal termination of the Tang Dynasty, economic and military power lay with regional commanders. These regional powers were practically kingdoms of their own. By the late ninth and early tenth centuries, wars and annexations had configured them into about eleven major states, one on the central plain of northern China and ten in other regions. This period was thereby named the Era of the Five Dynasties and Ten Kingdoms (the "five dynasties" refer to the series of powers in control of the northern China central plain and the "ten kingdoms" refer to the ten smaller states in other regions). Political fragmentation, competition, and economic development of this period continued into the succeeding Northern and Southern Song Dynasties and produced high levels of cultural economic achievements-levels that were not repeated in the China of either the Chinese Ming or Manchurian Oing era. These achievements are known as the Song Puzzle.

By 979 AD, the Song Dynasty, which originated in northern China, had conquered most of southern China. However, Yunnan province was in the hands of the Tali Kingdom, a tribal confederation of Thai peoples, and Vietnam achieved independence from China during the Era of Five Dynasties and Ten Kingdoms (907-960 AD). Another power of this state system was Tibet. Northern China was in the hands of three major powers: the Song Dynasty, which controlled the plain along the middle and lower stretches of the Yellow River; the Liao Kingdom (907-1125 AD), which controlled the Manchurian plain, inner Mongolia and parts of the northern China Plain; and the Kia Kingdom (1032-1227 AD), which controlled the Gansu Corridor and the upper stretch of the Yellow River valley. Of these three major powers, the Song Dynasty had the dominant share of the population and of economic and industrial might. However, the Liao and Xia Kingdoms, both highly sinicized semi-nomadic and semi-agrarian societies, together almost monopolized a very important strategic item: horses. Hence although Song China had greater economic might, relative combined military and economic efficiency among the three major powers were quite even and so was the distribution of military capability.

The Xia and Liao Kingdoms were unlike the nomads who constantly harassed the borders of China. The nomadic tribes lacked the resources to really conquer China, the cultural sophistication to administer China, or the economic and fiscal efficiency to engage China in prolonged, large-scale military struggle. The Xia and Liao kingdoms, besides having strong military power due to the possession of horses and skilled horsemen, also controlled a sizable amount 
of resources, commercial networks and industrial capacity. They also had the support of bulky and strong state machinery. Given their control of large tracts of settled territory, these two semi-nomadic semi-agrarian states were more akin to the earlier Northern Dynasties of 386-581 AD, which had ruled over northern China and posed a serious threat to the indigenous Chinese regime in the south. Established by nomadic tribes which had successfully assimilated Chinese culture and statecraft, the Northern Dynasties proved to be more than the political and military match of the Chinese regime in the south and their political achievements laid the foundation for the unifications led by the northern powers of the Sui and Tang Dynasties.

If the fact that the semi-nomadic states of Xia, Liao and Jin made up for their inferiority in economic resources with superior military efficiency is ignored, Song China would be classified as another example of an imperial power commanding a preponderant share of capability. The truth however is that Song Dynasty China was more like the bipolar era of the Northern and Southern dynasties, rather than similar to the short-lived imperial orders of the Sui and Tang dynasties. The Song Dynasty was even more unlike the stable and enduring imperial orders of the Oin Dynasty and Han Dynasty or, the Yuan, Ming and Qing dynasties that came after.

For all that the Song may have claimed dynastic control over the whole of China, the three major states of Song-era China treated each other as worthy rivals. In fact, Song Dynasty often had to pay tribute to her northern rivals to maintain peaceful relationships. ${ }^{142}$ Of the three major states, the Northern Song and Liao were the most powerful players. The Liao Kingdom's territorial size was twice that of the Northern Song. The Jurchen Jin Kingdom eliminated the Liao Kingdom in 1125 AD and occupied Liao territory, as well as annexing the middle and lower stretches of the Yellow River region from the Song Dynasty. Militarily the Liao and Jin Kingdoms were usually on the offensive whilst the Song Dynasty was on the defensive.

After 1127 AD, the Song Dynasty, which retreated to the southern part of China, and the Jin Kingdom (1115-1234 AD) were about equally matched. Songera China was therefore a tri-polar state system. The economic powerhouse of the Song Dynasty was southern China, especially the middle and lower stretch of the Yangtze River basin. The loss of the northern China central plain by the Southern Song Dynasty therefore was not a significant blow economically.

During the Song Era, due to the pressure from the northern rival states, there were many military technological innovations. To meet with the threats from powerful rivals, the Song Dynasty put significant effort into researching the use

142 Refer to Lee (1988). 
of gunpowder in warfare. Other innovations in military technology included a greater use of mechanical missile devices which increased the power of the infantry (during the Northern Song Dynasty). There were widespread uses of gunpowder weaponry during the Southern Song Dynasty. Song China and its rivals maintained large-scale standing armies and navies. The large scale of the defense forces in the Chinese competitive state system was greater than that seen in Europe until the Napoleonic wars. ${ }^{143}$ Keenly aware of its military disadvantage due to the short supply of horses, Song China strove to at least partially make it up through greater economic might and technological superiority. An extensive network of industrial-military development was maintained to tap economic resources and technological prowess for military use.

Unlike the decentralized Tang Dynasty, Song China was a very centralized service state which intervened extensively to help advance the economy. Song China produced many capable statesmen, of which the great reformer Wang An-Shih (1021-1086 AD) was the most famous. Wang's reform programs aimed to create a service state for greater economic might and military prowess, all in order to meet the challenge posed by the northern rival states. Wang also tried to trim down the over-sized state sector and increase its efficiency. State civil employees numbered in the millions during the Song era, as did military personnel. Wang's reform effort was from 1069-1085 AD, when he was the prime minister. Wang, however, was neither the first nor the last reform-minded prime minister of the Song Dynasty.

On the legal-institution front Song China was innovative without being revolutionary. The Song Dynasty retained the basic legal framework inherited from the Tang Dynasty and made extensive use of imperial edicts to handle new economic realities and changes. These imperial edicts were administrative orders that, in essence, replaced the Song Codes which followed the legal framework of Tang Codes and the Kai Huang Lu of Sui Dynasty. Such flexible and expedient measures allowed the legal institutions of the Song Dynasty to cater to the new commercial and industrial sectors without challenging the fundamentals of the traditional legal system. ${ }^{144}$

The economy prospered with elaborate internal and external trading networks. ${ }^{145}$ The members of the global trading network of this period included Southeast Asia, India, the Middle East and Europe. External trade brought in close to half of the state revenue: the economy was so commercialized that soon after 1000 AD the Song government found it more convenient to collect taxes in cash instead of in kind. There was sustained growth in per capita

143 Refer to McNeill (1982) and Keegan (1993).

144 Refer to Head and Wang (2005, p. 145).

145 Refer to Abu-Lughod (1989) for the global trading network at this period. 
income during this era and China was the industrial center of the global trading system. Jones (1990) notes that:

"Under the Song, at any rate, there is evidence of: a) structural change (when labor moved from primary production to higher-yielding secondary or tertiary production; in the modern world this is positively associated with rising per capita GNP); b) the large-scale purchase of consumer goods; c) and widespread, quite advanced, technical innovation." (7)

Song China led the world in shipbuilding and maritime technology. Song China's innovations include the invention of the compass, the adjustable centerboard keel, and the use of cotton sails in place of bamboo slats. ${ }^{146}$ This maritime technology and know-how was used in naval warfare between the Southern Song Dynasty, the Jin Dynasty and the Mongolian regime. These were large-scale engagements with hundreds, and at times thousands, of seagoing ships employed. Song China explored parts of maritime Southeast Asia, including Taiwan and the Philippines. The maritime achievements of the Song Dynasty laid the foundation for the later and perhaps more famous overseas expeditions undertaken by the famous eunuch Admiral Zheng He and others during the early Ming Dynasty.

During this period, China experienced a burst in technological and economic progress. ${ }^{147}$ For instance, Song China invented and disseminated a water-powered hemp-spinning machine, whereas similar devices in Europe only appeared around $1700 \mathrm{AD} \cdot{ }^{148}$ By the end of the $11^{\text {th }}$ century, China's total iron output had seen a peak of 150,000 tons; total European output only matched these levels some six centuries later. ${ }^{149}$ Effectively, Chinese iron output per capita at the close of the $11^{\text {th }}$ century was some twenty per cents greater than that of Europe. The invention of the unmovable printing press during the late Tang Dynasty and the invention of the movable printing press during the Southern Song Dynasty greatly facilitated the spread of information and led to greater efficiency in public administration as well as higher economic productivity. Three of the four greatest inventions of China were made during the Song Dynasty: namely, gunpowder, printing, and the compass. (The fourth, paper, had been invented earlier, during the Eastern Han Dynasty.) The superior economic performance of Song China is also testified to by the fact that the Song Dynasty was the only

146 Refer to Stavrianos (1982, p. 283).

147 Refer to Cipolla (1967, pp. 101-2) and Graham (1973).

148 Refer to Elvin (1973). In later periods China however actually abandoned the use of this machine and regressed in terms of industrial technology. Refer to Jones (1981, p. 64). 149 Refer to Hartwell (1966) and Harrison (1972, p. 290). 
major Chinese dynasty that had no large-scale peasant rebellion. There were also major changes in land ownership and educational reorganization.

The Song Dynasty's cultural achievements were equally impressive: the porcelain manufactured during the Song Dynasty was the best in quality and design; the most important works of Neo-Confucianism were completed; poetry and other literary works flourished, with the comprehensive historical works of Chi Zhi Tong Jian, by Shi Ma Guang, appearing. ${ }^{150}$ Such a miraculous performance was not repeated in the subsequent powerful and unified Ming and Qing periods. ${ }^{151}$

Commenting on the intensive growth of Song China, Stavrianos (1982) notes:

"In addition to its cultural attainments, the Song period is noteworthy for a commercial revolution with much significance for all Eurasia. The roots are to be found in a marked increase in the productivity of China's economy. Steady technological improvements raised the output of the traditional industries. Agriculture likewise was stimulated by the introduction of a quickly maturing strain of rice that allowed two crops to be grown each season where only one had been possible before. Also new water-control projects undertaken by the Song greatly expanded the acreage of irrigated paddy fields. Thus it is estimated that the rice crop doubled between the eleventh and twelfth centuries. Increasing productivity made possible a corresponding increase in population, which in turn further stimulated production in circular fashion. The volume of trade also rose with the quickening tempo of economic activity. For the first time there appeared in China large cities that were primarily commercial rather than administrative centers." (282-283)

Stavrainos (1982) further observes that Song China was the first government to introduce paper money, which facilitated commerce. Song China exported mostly manufactured goods, including silk, porcelain, books and paintings, and imported mostly raw materials such as spices, minerals and horses. This trade pattern testified to Song China's global economic leadership. ${ }^{152}$

Bernholz and Vaubel (2004) comment that:

"Under the Song dynasty (960-1275), which faced severe international competition and had to pay tribute to neighbouring 'barbarians' for most of its

150 Refer to McNeill (1999, p. 253).

151 Refer to Jones (1981, p. 202) and Bernholz and Vaubel (2004, p. 6).

152 Refer to Stavrainos (1982, pp. 283-4). Refer to Deng (2000) for a survey of works on Chinese economic history. Refer to Wesson (1967, pp. 204-205) for the developmental achievements of Song China. 
reign, China advanced to the threshold of a systematic experimental investigation of nature and created the world's earliest mechanized industry. Private printing was popular, and water-powered machines for spinning hemp thread appeared. The government promoted education, irrigation and trade, including maritime and foreign trade. Military technology was at a high level. The Song period was both the climax and the end of scientific technological progress." (5)

The experience of medieval China, from the collapse of an indigenous Chinese regime in northern China during the Jin Dynasty to the end of the Southern Song Dynasty, was largely one of political fragmentation and competition as well as intellectual creativity and economic development. It largely accords with the main arguments of this book. Of special importance were the innovations of Song China in military technology which sowed the seed for the next major round of military technological change, that of the gunpowder military revolution.

Given the intense political-military competition of the Chinese system during the Song era, Song China led the world in military technological innovations. ${ }^{153}$ Around $900 \mathrm{AD}$, China began to undergo major changes in military technology. The use of gunpowder-based weapons proved to be especially revolutionary. The destructive power of gunpowder was soon harnessed to bring down fortresses and other defenses, and this invention gradually spread to the other major cultures of the old world, including Europe, through the Mongolian empire. This was the beginning of the Gunpowder Military Revolution which, along with the concomitant innovations of the printing press and compass, began to fundamentally change the world. ${ }^{154}$

The Mongolian military combined the battlefield mobility of light cavalry with the military technological breakthroughs generated by the intensely competitive and highly innovative Chinese international political system to conquer a large part of the Eurasian land mass. The Mongolian Empire had greater war efficiency and a larger pool of resources at its disposal than the earlier northern rivals of Song China. Relative combined military and economic efficiency had become more asymmetric. The economies of scale in warfare had become greater too, due to the use of gunpowder, especially in overcoming fortresses and other defenses. Consequently, there was a greater concentration of resources and capability in the hand of the leading political-military power. The Mongolian Empire therefore embarked upon a path of far-flung conquests

153 Refer to McNeill (1982) and McNeill (1999, Ch. 14). McNeill (1982) refers to the period from B. C. 200 to A. D. 1200 as the millennium of Chinese leadership in military technology.

154 Refer to Needham, Ho, Lu and Wang (1987). 
hitherto unknown in history. The Mongolian Empire then used the resources so acquired to overrun the Southern Song Dynasty. The conquest of Southern Song Dynasty by the Mongolian Empire ended the medieval fragmentation of China and with it the Song Puzzle.

\section{Japan}

The medieval era saw the entrance of Japan into the civilized world. By the end of the $4^{\text {th }}$ century, the rulers of the Yamato plain in Honshu had created an extensive kingdom. During the $6^{\text {th }}$ century, Prince Shotoku further transformed the Yamato Kingdom by strengthening the authority of the court over the provincial nobles and building an administration based on the Chinese model. ${ }^{155}$ The influence of Tang China was extensive. Japan adopted the Chinese model of military and central government. Japan also borrowed the Chinese writing system and other aspects of Chinese culture, such as Confucianism and Taoism. ${ }^{156}$ This period was referred to as the Taka era of sinicization.

The centralization scheme succeeded only partially at most. The central state in Japan was never able to consolidate its authority. Japan has a highly fragmented geography: the four major islands are very mountainous, and mountain ranges dissect these islands into many compartmentalized small coastal plain core areas. Due to the highly fragmented geography which aided peasants' resistance, central taxation of the agricultural sector was not effective; public administration devolved into decentralized local units. There arose the large estates which formed the economic foundation of feudalism, which lasted from around the $11^{\text {th }}$ to the $15^{\text {th }}$ century. ${ }^{157}$

The trend toward decentralization and fragmentation was reinforced by the introduction of horses and cavalry warfare from the Eurasian mainland. Given the medieval military technology, the Japanese system had small economies of scale in warfare. Consequently, there was a highly even distribution of resources and capability among the many contesting units. Feudalism and warlord politics replaced centralized government. In place of the imperial court, the military leadership of the shogunate exercised effective rule, though not in name (power was of course officially held by the emperor). Yet, by the late medieval period (ca 1150-1200 AD), even the shogunate and feudal lords found it hard to control the society, particularly the peasantry.

155 Refer to Haywood (1997, pp. 112-113).

156 Refer to Raaflaub and Rosenstein (1999, pp. 52-56).

157 Refer to Haywood (1997, pp. 228-229). 
From the onset of the daimyo (ca 1330 AD), but prior to the unification of the country under the Nobunaga, Hideyoshi and Tokugawa Shogunates, there were several hundred feudal units in Japan. Given the highly even distribution of capability, even with the small factor due to the medieval form of warfare, there was a significant amount of relativist concern generated. Moreover, there was no highly risk-averse power-induced risk attitude to distort economic decisions or hold back creativity given the highly even distribution of capability. Consequently, it was a period of rapid economic growth with important technological advances in agriculture and handicrafts. There was the transition from the barter economy to the money economy, with a significant increase in foreign trade. Japanese traders were active throughout Southeast Asia by the late fourteenth century. ${ }^{158}$

The succeeding period of 1467-1573 AD, one of intense military contests for power, is known as the Era of Warring States in the history of Japan. Firearms were imported from the West, especially through Portuguese and Dutch traders: the gunpowder military revolution thus affected Japan. The gunpowder military revolution raised the economies of scale in warfare of the Japanese system. There were heightened political-military competitions between the warlords. Relativist concern was elevated to a new height and generated hectic economic developments among the Warring States of Japan. There were extensive irrigation works, mining, trade, highway construction, fiscal capacity development and rapid urbanization. The intense political-military competition among the many warring states ended only with the ultimate unification of Japan under the Tokugawa Shogunate.

\section{Eurasia}

The mega Eurasian international political system had taken a more concrete shape during the medieval era. The dominance of light and heavy cavalry in battlefields gave medieval military forces great mobility and projection power through geographical space. Consequently, political and military competition among the major Eurasian cultures increased. Parallel to the development of greater overland projection power of the medieval military forces was the formation of a Pan Eurasian maritime trading network that knitted together all the major regions: Europe, the Middle East, South Asia, Southeast Asia and East Asia. ${ }^{159}$ The Islamic civilization was the linchpin in both the medieval mega

158 Refer to Stavrianos (1982, pp. 292-293).

159 Refer to Abu-Lughod (1989). 
Eurasian international political system and the medieval pan Eurasian maritime trading system. Therefore, the medieval major cultures were keenly aware of the existence of each other and were in constant cultural and economic and even political and military contacts. ${ }^{160}$

Despite the frequent contacts, none of the interactions between the major cultures had a political-military nature that was frequent or serious enough to generate sustained and significant relativist concern, with the exception of the political-military competition between the Middle Eastern based Islamic empires and states and the Byzantine Empire and European states. Consequently, political competition between (rather than within) the major cultures was not a major force for generating sustained and significant development effort. In other words, though the Eurasian mega international political system and mega international economic system took a more definite shape in the medieval time than during the late classical era, the mass factor between the major Eurasian cultures was still too small during the medieval era to spur substantial developmental drive.

Of all the relationships between the major cultures, that between China and the Middle East had gone through the most drastic change from the late classical era to the medieval period. Unlike the Chinese-Persian relationship of the late classical era, which a complete non-rivalry, there was for a brief period an acute political-military competition between China and Islam over the control of Central Asia. At the peak of its power, the Tang Dynasty of China established military bases in Central Asia for the protection of the Silk Road, something that China had not done for a long time-not since the collapse of the Han Dynasty. Yet, in the Battle of Talas (751 AD), the forces of China's Tang Dynasty were defeated by the Arabian army of the newly-founded Abbasid Caliphate. This defeat, together with the internal turmoil started by the Rebellions of An Lu Shan and Shi Si Ming, prompted China to retreat from Central Asia. Since then the two major cultures had no significant political-military competition given the great distance between them. So although China and the Middle East had little direct rivalry at the beginning or at the end of this period, there was for a brief time intense competition over Central Asia.

The political-military relationship between China and India during the medieval era was very different from that which existed between China and Islam. Medieval India was politically much more fragmented than China. Therefore, it was a one-way exertion of political-military influence by China on India when China was strong: India itself had little political military influence over China. At the peak of its power, the Tang Dynasty of China established

160 Refer to Frank and Gills (1993) and Franks (1998). 
military outposts in northern India to protect its interests. But all these ended with the defeat of Tang forces at the hands of the Arabian army in the Battle of Talas. In sum, the almost impassable Tibetan Plateau and the Himalayan Ranges effectively isolated and buffered China from direct political military competition with the two adjacent major cultures of Islam and India before the modern era.

During the medieval era, Islamic forces made constant incursions into the politically fragmented medieval Indian state system. There was no Tibetan Plateau or Himalayan Mountains to buffer or isolate India from the constant encroachments of Islam. There were many conversions to Islam, mostly from the lower castes in the Hindu society who were attracted by the egalitarian teachings of Islam. The political-military competition among the Hindu states and with the Islamic forces generated some sustained development, especially in southern India.

Other than China and the Middle East, Southeast Asia was the major region closest to India. However, mainland Southeast Asia was separated from India by geographical barriers of torrential rivers, impenetrable forests and high mountains. The Indian Ocean and Bengal Bay were less hostile but nonetheless significant barriers between the South Asian subcontinent and maritime Southeast Asia. Due to the vast distance and rough terrain between them, there was no significant sustained political-military competition between the two major regions during the medieval era. A rare exception was in the eleventh century, when the southern Indian maritime Chola Empire had naval expeditions to Southeast Asia and clashed with the Srivijaya Empire which was based in southeastern Sumatra. Though it severely undermined Srivijayan hegemony, the Chola invasion was ultimately unsuccessful.

The most intense political-military competition between the major cultures was that between Islam and the West. The Islamic Caliphate expanded into Central Asia, South Asia and Southern Europe, and the threat from Islam is often cited as one of the reasons for the rise of the West. Islamic advancement generated significant relativist concern in the Western world, especially in the Byzantine court and the Christian principalities bordering the Islamic world. The series of Crusades in the $11^{\text {th }}, 12^{\text {th }}$ and $13^{\text {th }}$ centuries, by Christian armies trying to retake Palestine from the Muslims, was one of the consequences of such concern. Partly due to the competition and contact with the Islamic world, Southern and Mediterranean Europe was the most advanced part of the Western world during the medieval era and Spain and Portugal spearheaded the great geographical discoveries and the European march towards world leadership.

Japan was probably the most geopolitically isolated major Eurasian culture during the medieval era. Situated on a string of islands located at the far eastern end of the Eurasian landmass, Japan was geopolitically isolated from 
practically all the other major Eurasian cultures except China. The great width of the East China Sea and the Japan Sea also almost ruled out persistent serious political-military competition between Japan and China, the other major culture that was closest geographically. During the medieval era, Tang Dynasty China fought with Japan in Korea in the Battle of Baekgang (663 AD): Japan was defeated and retreated, but the Tang Dynasty however was in turn driven out of Korea by their erstwhile Korean ally about a decade later. After this conflict, the two major cultures had no military contacts for centuries.

The Mongolian Empire was the first truly pan-Eurasian power. It had direct military contacts and competition with practically all the major Eurasian cultures: its military campaigns reached Europe, Japan, South Asia, Southeast Asia and the Middle East. Despite striking fear into the hearts of many across Eurasia, many of these ambitious far-flung campaigns either failed disastrously or ended inconclusively, due to vast distances and difficult terrain and weather conditions, despite the advanced weaponry and dominant resources of the Mongolian Empire. The empire was divided into four major realms for administrative purposes because of difficulties in communication and control over such vast distances, but despite such measures soon the empire broke down and dissolved. In other words, the mass factor was still too small on a pan-Eurasian level to sustain a stable pan-Eurasian empire or to generate significant and persistent political-military competition among the major cultures under normal circumstances, given the pre-industrial technology.

\section{Conclusions}

The use of heavy cavalry in the medieval era made cavalry the dominant force in battlefield and reduced the economies of scale in warfare. The smaller mass factor brought about massive structural changes in geopolitics. Continental size empires of the late classical era either retreated or dissolved. Political fragmentation was the norm in the long medieval era. Due to this fragmentation in the geopolitical landscape, during the medieval era, all major Eurasian civilizations exhibited significant though not miraculous creativity. Among the medieval bursts of creativity, China and the Middle East stood out and produced the most outstanding cultural and economic achievements, known respectively as the Song Puzzle and the Abbasid Golden Age. Yet the medieval Chinese and the early Islamic international political systems were hardly good examples of the state system. These achievements therefore seem to contradict the Hume-Kant Hypothesis and present difficulties for Bernholz and Vaubel (2004). The argument proposed by this book, with its more general theoretical underpinning, has no problem in dealing with these two cases as 
well as accounting for the developmental performance among the major cultures during the medieval era. That is to say, the experience of the medieval era agrees with and lends further support to the main argument of this book that military technology shapes the geopolitical landscape and that political military competition leads to cultural and economic creativity. 
Musket, Map and Money:

How Military Technology Shaped Geopolitics and Economics 